\title{
Spawning behavior of Aedini (Diptera: Culicidae) in a remnant of Atlantic Forest in the state of Rio de Janeiro
}

Amanda Queiroz Bastos ${ }^{1,2}$, Paulo José Leite ${ }^{1}$, Jacenir Reis dos Santos-Mallet ${ }^{3,4}$, Cecilia Ferreira de Mello ${ }^{1,2}$, Michele Serdeiro ${ }^{1}$, Júlia Santos dos Silva ${ }^{1}$, Ronaldo Figueiró ${ }^{5,6,7}$, Tatiana Docile $e^{8,9}$ and Jeronimo Alencar ${ }^{1 *}$ (D)

\begin{abstract}
Background: Mosquito assemblages are organized along an ecological gradient, including small habitats where interspecific competition predominates and large permanent habitats where predation predominates. This study aimed to analyze the oviposition behavior of mosquitoes regarding the preference for traps installed at two different heights with regard to ground level and the tendency to share spawning sites in an Atlantic Forest fragment in Nova Iguaçu, State of Rio de Janeiro, Brazil.
\end{abstract}

Methods: The eggs were collected from April 2018 to March 2019. Twelve ovitraps were used, randomly distributed in trees at ground level and at a height of $3 \mathrm{~m}$ in a forest environment.

Results: They were sequentially numbered, monitored, and replaced every 2 weeks. Among the 5818 eggs collected, 3941 hatched, 3756 reached the pupa stage, and 2370 reached the adult stage. The most abundant species were Aedes albopictus (63\%) and Haemagogus leucocelaenus (35\%), followed by Aedes terrens (2\%) and Haemagogus janthinomys (1\%). Analyses showed a significant difference of $(P=0.02)$ between the number of mosquito species collected in the palettes at ground level and the number collected at the height of $3 \mathrm{~m}$. Cluster analysis of species abundance showed that the eggs collected in the palettes at ground level were more abundant than those collected in the palettes at the height of $3 \mathrm{~m}$. We detected co-occurrence of species in the oviposition palettes; according to the null model, such species distribution was not random.

Conclusions: The exploitation of oviposition sites by mosquito species can represent an event forced by population density facilitated by the ecological valence of individuals of one species. Understanding the aggregate distribution of larvae at the oviposition site allows us to conduct more in-depth studies of the oviposition behavior of female mosquitoes.

Keywords: Mosquitoes, Oviposition biology, Coexistence, Natural environment

\footnotetext{
*Correspondence: jalencar@ioc.fiocruz.br

${ }^{1}$ Laboratório de Diptera, Instituto Oswaldo Cruz (FIOCRUZ), Rio de Janeiro, Brasil

Full list of author information is available at the end of the article
}

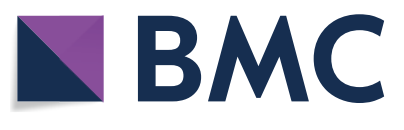

(c) The Author(s) 2021. Open Access This article is licensed under a Creative Commons Attribution 4.0 International License, which permits use, sharing, adaptation, distribution and reproduction in any medium or format, as long as you give appropriate credit to the original author(s) and the source, provide a link to the Creative Commons licence, and indicate if changes were made. The images or other third party material in this article are included in the article's Creative Commons licence, unless indicated otherwise in a credit line to the material. If material is not included in the article's Creative Commons licence and your intended use is not permitted by statutory regulation or exceeds the permitted use, you will need to obtain permission directly from the copyright holder. To view a copy of this licence, visit http://creativecommons.org/licenses/by/4.0/. The Creative Commons Public Domain Dedication waiver (http://creativeco mmons.org/publicdomain/zero/1.0/) applies to the data made available in this article, unless otherwise stated in a credit line to the data. 


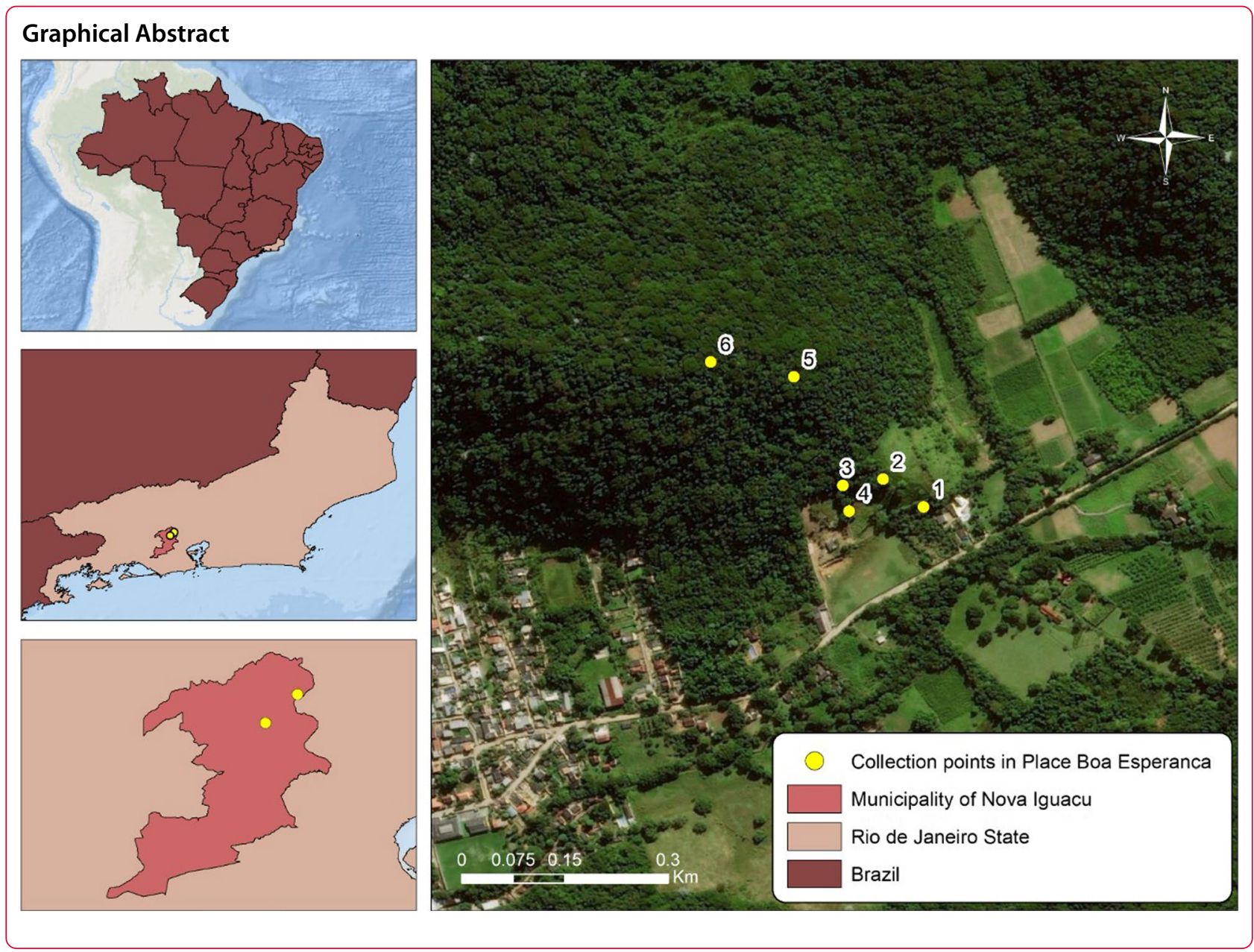

\section{Background}

Mosquitoes have attracted considerable attention due to their role in the transmission of important etiological agents such as arboviruses (e.g., Zika, dengue, chikungunya, and yellow fever) and malaria [1], thus leading to severe problems in health services in Brazil. There are 3583 recognized mosquito species, distributed across approximately 113 genera [2], or 42 genera according to the more traditional classification of Wilkerson et al. [3]. The Neotropical region has the highest level of endemicity, with $27 \%$ of species restricted to this biogeographic region [4].

According to Mondet et al. [5] and Araújo et al. [6], the yellow fever virus has been detected from north to south of Brazil, with cyclic epizootics, human cases, and virus isolation reported for Haemagogus janthinomys (Dyar, 1921) and Haemagogus leucocelaenus (Dyar \& Shannon, 1924). Haemagogus janthinomys is considered the main vector of wild yellow fever (WYF) [7]. However, Hg. leucocelaenus is the most common species of the genus in Brazil and was recently found naturally infected with the WYF virus in the state of Rio de Janeiro [7].

The selection of vessels as spawning sites by mosquitoes depends on the species' eclecticism in the use of the type of vessel and the place where it is located. Moreover, some factors can influence the pregnant female's choice of oviposition site, including color, consistency, and vessel size [8]. Most mosquito species need at least two blood meals for the first egg-laying to develop and for oviposition to occur on the 4th or 5th day [9].

Fader [10] reports a differential resource hypothesis, suggesting that mosquitoes can lay eggs in vessels with high-quality resources. According to Alencar et al. [11], the environmental factors to which the eggs of Haemagogus are exposed in the field can influence the hatch rate in the laboratory; therefore, some eggs may need more than one water immersion event to hatch.

Serpa et al. [12] stated that pregnant females of Aedes aegypti (Linnaeus, 1762) select vessels containing water with conspecific larval rearing water, suggesting this species' preference for pre-existing spawning sites in an 
attempt to reduce the effects of intraspecific competition. Competition for limited resources is much better known than specific differences in resource acquisition and use [10]. The highly asymmetric interspecific competition will often result in the exclusion of the inferior competitor [10].

Mosquitoes from the Aedini tribe show a tendency for temporary spawning sites in wild environments, such as species of the genus Haemagogus, which are found colonizing cut bamboos, tree hollows, and coconut shells [13]. Interactions like competition, predation, and mutualism among mosquito larvae can provide valuable models for testing and developing ecological theory for effects dependent on habitat, size, predation intensity, resource availability, or structural complexity [14].

Serpa et al. [12] reported that the effect of water where conspecific and heterospecific larvae hatch as a result of oviposition can contribute to the understanding of the ecological relationships between species as well as assess the reproductive potential of emerging females from spawning sites with coexistence of species.
This study aimed to evaluate the oviposition behavior of mosquitoes regarding the preference for ovitraps installed at two heights in relation to ground level and the tendency to share spawning sites in a fragment of Atlantic Forest in the state of Rio de Janeiro, Brazil.

\section{Methods}

\section{Study area and sampling}

Collections were carried out at the Boa Esperança farm (S22 $35^{\prime} 16.2^{\prime \prime}$; W043 $\left.{ }^{\circ} 4^{\prime} 28.9^{\prime \prime}\right)$ located in the city of Nova Iguaçu, state of Rio de Janeiro, Brazil (Fig. 1). The region has a humid tropical climate with an average annual temperature of $21.8^{\circ} \mathrm{C}$ and an average annual rainfall of $2105.1 \mathrm{~mm}[15]$.

Ovitraps were used for egg collection. This type of trap consisted of a $500-\mathrm{ml}$ lid-less matte black pot with four plywood palettes (Eucatex ${ }^{\circledR}$ plates) held vertically inside the trap by clips. Natural water and litter (remains of leaves and decaying organic material from the soil) were added to the ovitraps to reproduce a microecosystem closer to the natural [4]. Traps

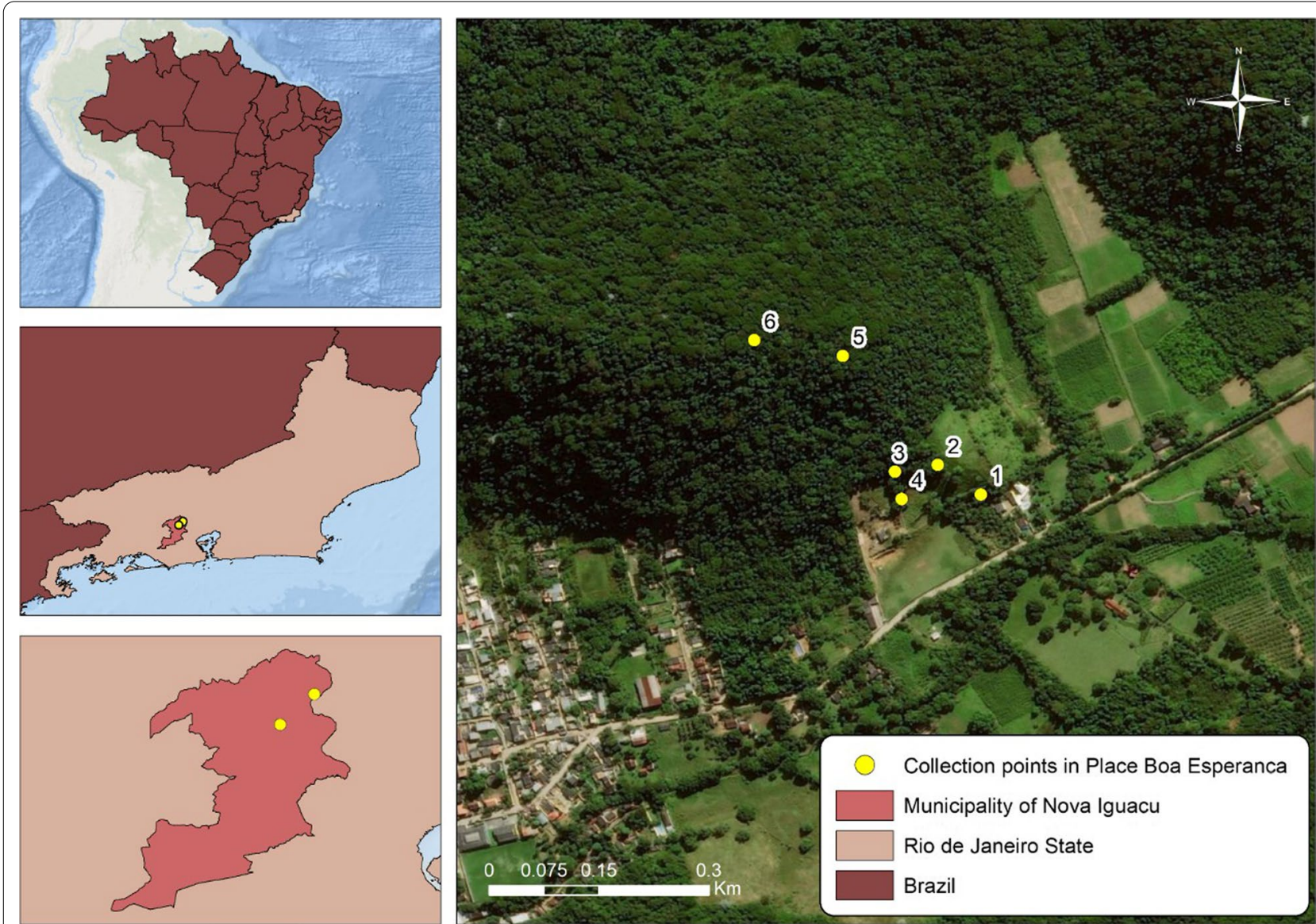

Fig. 1 Sampling sites in Boa Esperança farm located in the city of Nova Iguaçu, state of Rio de Janeiro, Brazil. Service layer credits: Source: Esri, Maxar, GeoEye, Earthstar Geographics, CNES/Airbus DS, USDA, USGS, AeroGRID, IGN, and the GIS User Community. On May 4, 2021 
were installed at the following collection points under the same conditions, at ground level and at $3 \mathrm{~m}$ from ground level.

Collection point 1 (P1S and P1M-S22 ${ }^{\circ} 35^{\prime} 15.3^{\prime \prime}$; W043 $\left.24^{\prime} 29.9^{\prime \prime}\right)$ is a secondary forest with recent reforestation and few trees, some nearby dwellings, and livestock. Collection point 2 (P2S and P2M-S22 $35^{\prime} 14.0^{\prime \prime}$; W043 $\left.24^{\prime} 31.8^{\prime \prime}\right)$ is characterized by a clearing with undergrowth and grasses, used for animal grazing. Undergrowth borders the arboreal stratum of collection point 3 (P3S and P3M-S22 $35^{\prime} 14.3^{\prime \prime}$; W043 ${ }^{\circ} 24^{\prime} 33.7^{\prime \prime}$ ), which is also used for animal grazing. Collection point 4 (P4S and P4M-S22 $35^{\prime} 15.3^{\prime \prime}$; W043 $\left.{ }^{\circ} 4^{\prime} 33.4^{\prime \prime}\right)$ is located around several bamboo plants. Collection point 5 (P5S and P4M-S22 $35^{\prime} 09.2^{\prime \prime}$; W043 $3^{\circ} 4^{\prime} 36.0^{\prime \prime}$ ) is situated inside the dense forest, and its vegetation with trees can reach up to $30 \mathrm{~m}$ in height. Collection point 6 (P6S and P6M-S22 $35^{\prime} 08.5^{\prime \prime}$; W043 $24^{\prime} 39.9^{\prime \prime}$ ) has a dense shrub layer with many larger trees and a dense crown. Twelve ovitraps were installed at a random distance, with two traps per tree: one trap in the ground (P1S, P2S, P3S, P4S, P5S, and P6S) and one trap at the height of $3 \mathrm{~m}$ (P1M, P2M, P3M, P4M, P5M, and P6M). They were then monitored and replaced every 2 weeks from April 2018 to March 2019. After the palettes were collected, they were placed in a polyethylene box and sent to the laboratory, where they were dried for 2 days at room temperature. Subsequently, the eggs were counted under a stereoscopic microscope.

The palettes were separated in the laboratory, submitted to egg counting, and individually immersed in transparent mesh trays of $27 \times 19 \times 7 \mathrm{~cm}$ containing dechlorinated water.

The eggs were maintained in a controlled experimental environment (greenhouse with thermoperiod and photoperiod), at a temperature of $28^{\circ} \pm 1{ }^{\circ} \mathrm{C}$, relative humidity of $75-90 \%$, and photoperiod of $12 \mathrm{~h}$ (day/night). The dwell time of the eggs in the greenhouse was about 3 days, and observations were made daily. After this period, the palettes were removed and the hatched larvae were counted. The palettes were then exposed for drying in the trays and conditioned for 3 days outside the greenhouse for reimmersion.

Species identification was carried out from direct observation of the morphological characters evident under an optical microscope (Leica DMD $108^{\circledR}$ ) and consultation of the respective descriptions/diagnoses of the species, using dichotomous keys developed by Lane [16, 17], Arnell [18], Forattini [19], and Marcondes and Alencar [13]. Subsequently, all specimens were deposited into the Entomological Collection of the Instituto Oswaldo Cruz, Fiocruz, Rio de Janeiro, under the title "Atlantic Forest Collection."

\section{Statistical analysis}

To evaluate and compare the diversity of mosquitoes at each collection point, the following indices were used: Shannon-Wiener $\left(H^{\prime}\right)$ [20] and Pielou's evenness index (which measures diversity along with species richness) $[21,22]$. Data were tested for normality [23], and those with normal distribution were submitted to a t-test [24] to verify significant differences between specimens collected on the ground and at the height of $3 \mathrm{~m}$. Non-parametric data were tested using the Mann-Whitney U test [25]. These tests were performed in Biostat 5.0 [26, 27]. All statistical tests were performed according to Zar [24].

To evaluate and compare differences in mosquito abundance at different collection points and respective heights, ecological distance was analyzed using cluster analysis, by the unweighted pair group method with arithmetic mean (UPGMA), using the quantitative Bray-Curtis similarity index performed in the statistical program PAST [28]. Analysis of the co-occurrence of spawning species in the same palette was performed in ECOSIM 7.0 [29]; in this analysis, a null model was used to test the hypothesis of observed patterns of species distribution to be random. The C-score index [30] was also calculated to measure the checkerboard units between all possible species pairs. In a community structured by competition, the C-score index should be significantly lower than what would be expected by the null hypothesis. In this analysis, a data matrix is used to calculate average co-occurrence. This matrix generates a series of simulated matrices through a null model to identify whether the calculated index differs significantly from what would be expected by chance.

The following parameters were used in the null model: sums of fixed lines representing the abundance of individuals of the species, in which the total values observed in the lines are kept in the simulation so that the number of occurrences of each species in the null communities is the same of the original data; sums of equiprobable columns, a configuration in which each column (or site) is equally likely to be represented. The values of the cooccurrence indices between each pair of species were also calculated.

\section{Results}

During the sampling period, 1152 palettes were collected from ovitraps that were at ground level and at a height of $3 \mathrm{~m}$. Of this number, 24\% (272) were positive for eggs, presenting 5818 eggs, of which 1877 did not hatch. Of the total number of eggs found, 2370 reached adulthood and were identified as Ae. albopictus ( $n=1486 ; 63 \%), H g$. leucocelaenus ( $n=823 ; 35 \%)$, Ae. terrens (Walker, 1856) ( $n=46 ; 2 \%)$, and Hg. janthinomys $(n=15 ; 1 \%)$ (Additional file 1: Table S1). Considering the overall sum, all 
species found occurred in greater abundance at ground level. Haemagogus leucocelaenus was more abundant in the forest area (point 5), showing the transition to collection point 1, where Ae. albopictus was more abundant (Additional file 1: Table S1). Compared to Ae. albopictus, $\mathrm{Hg}$. leucocelaenus was more frequent in traps located at the height of $3 \mathrm{~m}$; however, $79 \%$ of the specimens preferred to spawn in the traps installed at ground level.

The Mann-Whitney test $(U=6.00 ; \quad Z=1.92$; $P=0.02$ ) revealed a significant difference in the abundance of mosquito species found in the palettes collected at ground level compared to those installed at the height of $3 \mathrm{~m}$ (Fig. 2). In the palettes collected at ground level, a greater abundance of mosquito species was observed. However, there was no significant difference in the other community parameters calculated (richness, diversity, dominance, and evenness) among the six collection points of the analyzed species (Additional file 2: Table S2). The greatest diversity values were observed in the traps located at ground level, at collection points $3\left(H^{\prime}=0.8367\right)$ and $5\left(H^{\prime}=0.8055\right)$, whereas the highest richness values were at collection points 5 and 6 ( $S=4$ for both points) (Additional file 2: Table S2).

The cluster analysis (Bray-Curtis index $=0.91$ ) applied to species abundance indicated that the palettes collected at ground level had the highest abundance of specimens, comprising a group with the collection points P1S, P2S, P3S, P5S, and P6S, while the palettes collected at the height of $3 \mathrm{~m}$ (P1M, P2M, P4M, P5M, and P6M) formed another less abundant group (Fig. 3). Only P4S at the ground level and P3M at the height of $3 \mathrm{~m}$ did not fit the expected abundance of these groups (Fig. 3).

According to the null model, co-occurrence and distribution of all species found in the different collection

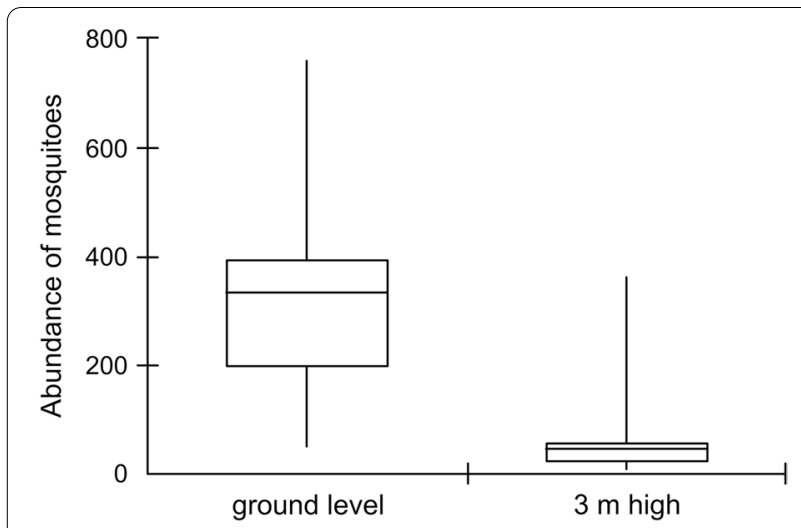

Fig. 2 Boxplot expressing the statistically significant result of the Mann-Whitney test for the abundance values of mosquito species in traps at ground height and above $3 \mathrm{~m}$. Mann-Whitney Test $U=6.00$; $Z=1.92 ; P=0.02^{*}$

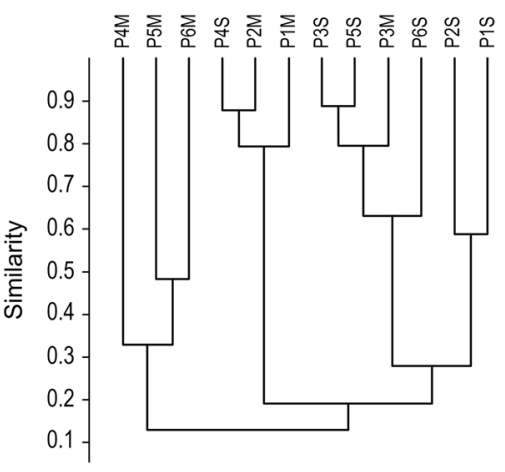

Fig. 3 Cluster analysis (UPGMA method) based on quantitative values of mosquito species abundance (Bray-Curtis index $=0.91$ )

points were not random (Additional file 3: Table S3). The distribution was structured: observed index $=60.83$; mean of simulated indexes $=89.05$; variance of simulated indexes $=225.80 ; p($ observed $\leq$ expected $)=0.02 ; p$ (observed $\geq$ expected) $=0.97$ (Fig. 4). The C-score index was significantly lower than expected by the null hypothesis (Additional file 3: Table S3; Fig. 4).

The graph of this analysis shows arrows pointed to the value of the $\mathrm{C}$-score index observed. This value is $\mathrm{d}$ in the part of one of the tails of the normal curve, indicating that it is significantly lower than expected by the null hypothesis (Additional file 3: Table S3; Fig. 4).

\section{Discussion}

The present study suggests an ecological valence in the oviposition behavior of Ae. albopictus, which was able to cohabit with other species in the same palette and was successful in surviving compared to other species found during the sampling period. Barbosa and Navarro-Silva [31] reported that Ae. albopictus has plasticity in the oviposition behavior, a characteristic related to colonization that is a critical epidemiological factor.

Analysis of the abundance showed that Ae. albopictus, Hg. leucocelaenus, and Ae. terrens were more abundant in traps located on the ground, while $\mathrm{Hg}$. janthinomy was more abundant in traps installed at the height of $3 \mathrm{~m}$. Silva et al. [32] recorded partially differentiated results, as they found the highest abundance at the height of $3 \mathrm{~m}$ for the last three species mentioned. In their study, $A e$. albopictus showed the highest number of specimens at ground level, with $52 \%$ of specimens collected.

The reproductive success of mosquitoes is related to selection of the oviposition site, a critical factor for survival and population dynamics. This selection influences larval distribution in the habitat and results from complex interactions of chemical and physical factors [33]. 


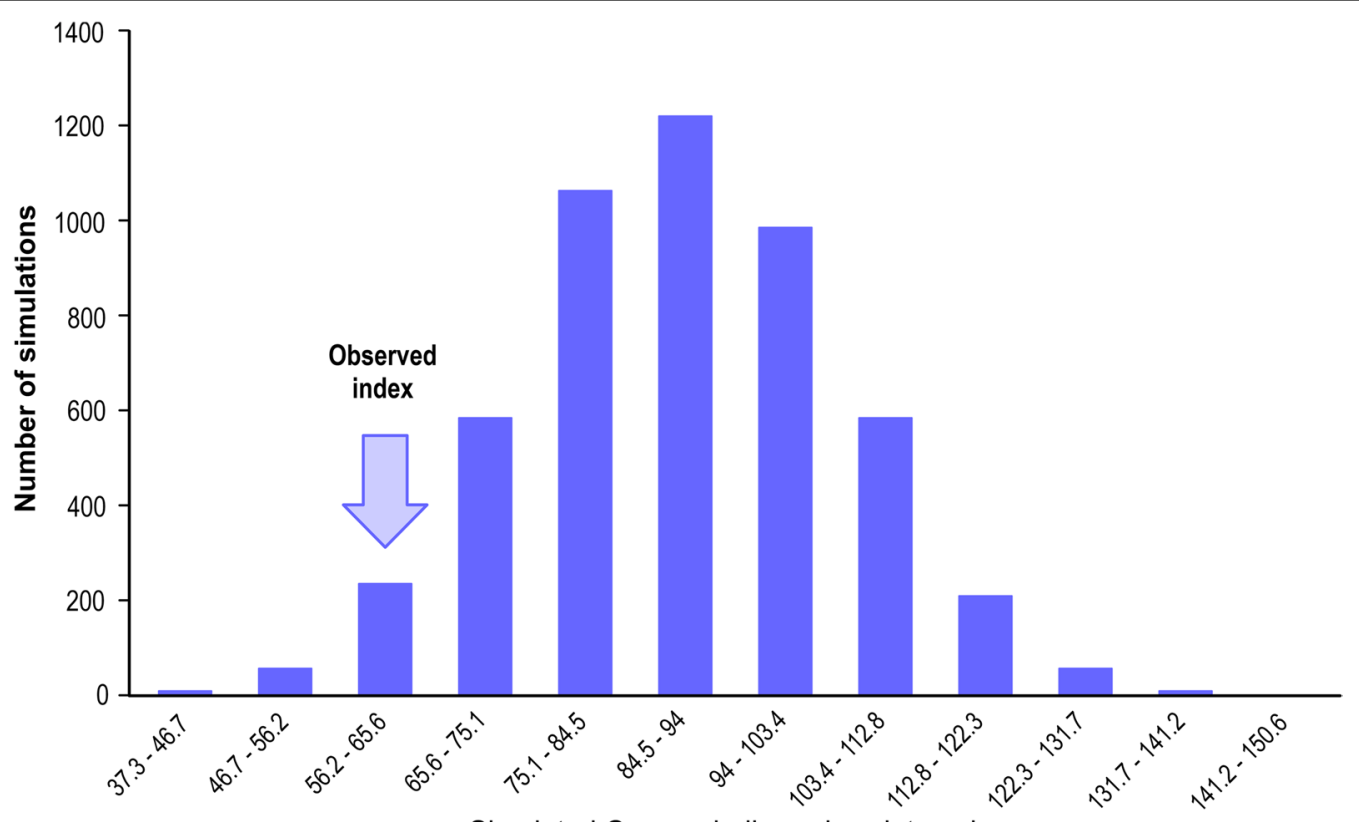

Simulated C-score indices class intervals

Fig. 4 Null model for co-occurrence of immatures [observed index $=60.83$, mean of simulated indices $=89.05$, variance of simulated indices $=225.80, p$ (observed $\leq$ expected) $=0.02, p$ (observed $\geq$ expected $)=0.97]$. The arrow indicates the value of the co-occurrence index from actual data

Aedes albopictus showed greater dominance during the sampling period. Zequi et al. [34] reported the wide occupation of spawning sites and the ecological valence of Ae. albopictus when colonizing wild and anthropic environments, laying posture in both natural and artificial spawning sites.

Honório and Lourenço-de-Oliveira [35] found Limatus durhamii Theobald, 1901, coexisting with Ae. albopictus and $A e$ e aegypti, suggesting that coexistence and the presence of immature forms of the same species in a spawning site indicate favorable conditions for species development. It is important to emphasize that 38 of the 272 positive palettes were shared by species, with 36 palettes shared by 2 species and 2 palettes shared by 3 species.

Beier et al. [36] observed that, although several species might cohabit, only one or two predominate. Similarly, in palettes with eggs of $\mathrm{Hg}$. leucocelaenus, the coexistence of two and three species in the same palette was detected in this study. Marques et al. [37] reported eggs from Ae. terrens found with those Ae. albopictus.

In addition, Ae. albopictus shared palettes with Ae. terrens, $\mathrm{Hg}$. leucocelaenus, and $\mathrm{Hg}$. janthinomys. This result differs from those of Alencar et al. [38], who found the eggs of only one species in the palette, and Chadee et al. [39], who reported that females have a tendency not to lay eggs in places where their eggs or those of other species are already found.
Evaluating the oviposition behavior of mosquitoes can contribute to developing strategies to attract pregnant females and monitor the early presence of species in anthropic ecosystems [31].

Analysis of the null model for co-occurrence revealed a smaller number of co-occurrences than expected by the null hypothesis; if co-occurrences were random, the value of the $\mathrm{C}$-score index would be higher. These findings reveal an ecological phenomenon structuring the population distribution, with competition possibly playing a role in the observed patterns, which structured the observed combination of species. Docile et al. [40] reported that immatures collected from bromeliads presented a structured distribution of specimens, not following a random pattern.

Schoener [41] suggested that niche overlapping observed in nature should occur at a lesser degree than expected at random and that a significantly small observed overlap may imply competition and resource partitioning [42]. Thus, the results of our simulations are consistent with the hypothesis that the observed patterns were not random and that the community structure was partially driven by competition and partitioning of a possible limiting resource; in this case, the space available when sharing the palettes inside the ovitraps.

Price [43] argued that female mosquitoes in the laying phase need to find a suitable place for daily oviposition. Females of different species should be expected to prefer 
oviposition sites associated with favorable conditions for the offspring [43]. Preferences for a particular type of spawning site for oviposition are exhibited by many mosquito species [33, 44, 45], and this choice is the result of a complex interaction between biotic and abiotic factors on which the survival of the aquatic stages of mosquitoes depends.

The search for these factors requires studying the use of the habitat (in this study, the ovitraps) and how this space and its resources are shared by the species found [46]. Therefore, the initial increase in mosquito populations in the spawning site should stabilize in response to reducing the amount of resources. Thus, oviposition behavior can influence the result of competitive interactions between species and, consequently, the structure of the mosquito community in the palettes.

Ecological successions carried out by different species can be responsible for the longest time with high population density due to the colonization of different species at different times of the year [8].

In a study conducted in Nova Iguaçu, Brazil, Honório and Lourenço-de-Oliveira [35] reported that Aedini larvae were rare in the winter period, especially in August, and more frequent in February, coinciding with the period of greatest rainfall. In line with the findings of those authors, the species of Aedini presented the lowest abundance in the winter and the highest frequency in the summer in the present study.

Couto-Lima et al. [47] reported that some Aedini species with desiccation-resistant eggs might die or migrate over a few months during the unfavorable weather season. However, those authors found Hg. leucocelaenus throughout their sampling period. On the other hand, no eggs of $\mathrm{Hg}$. leucocelaenus were collected during winter in the present study.

Zequi et al. [34] reported that all species collected had a decrease in their population densities in the coldest months of the year. This direct influence of temperature on the activity of mosquitoes, as well as the population increase in the hottest and rainiest periods of the year, is widely known [34].

The eggs of Ae. terrens were found exclusively in the ovitraps installed at ground levels. Similarly, Alencar et al. [38] found that $\mathrm{Hg}$. janthinomys was predominant in the palettes collected from the tops of the trees and $A e$. terrens in the traps installed in the ground. In the present study, Ae. albopictus was dominant at the two heights where the ovitraps were installed, and $\mathrm{Hg}$. leucocelaenus showed greater abundance in the collection point with dense forest.

Tátila-Ferreira et al. [48] suggested that the availability of resources is the leading indicator of the abundance of $H$ g. leucocelaenus in the different strata. Indeed, several authors consider the oviposition site as the main factor affecting the dispersal of female mosquitoes (e.g., TátilaFerreira et al. [48]).

Camargo-Neves et al. [49] found that Hg. leucocelaenus has a greater ability to adapt to modified environments when compared to other species of the genus. Their findings are in line with the present study, in which $\mathrm{Hg}$. leucocelaenus was abundant in the sample site with the same vegetation characteristics.

Fader [10] suggests that mechanisms that alter interand intraspecific competition can explain variable coexistence patterns and predict future species distribution as well as understand the consequences for resident species that interact with mosquitoes.

The cluster analysis shows a group of the most abundant species of eggs collected from the traps installed at ground level and another group formed with eggs of less abundant species in the palettes collected at the height of $3 \mathrm{~m}$. It should be noted that this finding is also evident when analyzing the absolute numbers of specimens collected at ground level and at the height of $3 \mathrm{~m}$. Alencar et al. [4] observed that mosquito diversity was higher in samples collected from ovitraps located at ground level and that the frequency decreased according to the height of the trap. This result can be explained by the low supply of hosts for feeding mosquitoes with blood [4].

Studying mosquitoes in a natural environment is essential for assessing possible changes in the behavior and adaptation of these insects according to the environmental conditions of regions that have undergone or are undergoing changes caused by humans, especially for epidemiologically important species [4]. Mosquito populations are organized along an ecological gradient that includes ephemeral habitats where interspecific competition predominates, and large predators are uncommon to large permanent habitats where predation predominates [14].

\section{Conclusions}

Our study suggests a pattern of species distribution related to intra- or heterospecific competition and the height at which females select the oviposition site. We believe that factors such as food resources should be investigated to understand the pattern of the population distribution of species of the Aedini tribe.

\section{Supplementary Information}

The online version contains supplementary material available at https://doi. org/10.1186/s13071-021-05102-9.

Additional file 1: Table S1. Absolute abundance of species from the Aedini tribe by collection point (1 to 6 ) collected on the ground and 
height $3 \mathrm{~m}$ in the sampling period from April 2018 to March 2019 at the Boa Esperança site in Tinguá, Municipality of Nova Iguaçu, State of Rio de Janeiro.

Additional file 2: Table S2. Values obtained for richness, abundance, dominance, Shannon (a) diversity, and Pielou's equitability for each of the 12 studied traps and the respective test values and $p .\left(^{*}\right) p<0.05$.

Additional file 3: Table S3. Values of the co-occurrence C-score indices between each pair of mosquitoes species found.

\section{Acknowledgements}

We thank CAPES for granting doctoral scholarships to Amanda Queiroz Bastos. We are also grateful to Nova Iguaçu health agents José Romero Costa de Oliveira e Souza and Sebastião Loures de Miranda Filho for their help during the field collections.

\section{Authors' contributions}

$\mathrm{AQB}$ and JA contributed with experimental design, data analysis and manuscript writing; CFM, PJL, and MS contributed with the organism identification and data analysis; JRSM, JSS, RF, and TD contributed with data analysis and manuscript review. All authors revised successive drafts of the manuscript. All authors read and approved the final manuscript.

\section{Funding}

This work was supported by the Rio de Janeiro Research Foundation (FAPERJ; grant no. E-26/202.658/2018; E-26/010.110076/2018).

\section{Availability of data and materials}

Not applicable.

\section{Declarations}

Ethics approval and consent to participate

Not applicable.

\section{Consent for publication}

Not applicable.

\section{Competing interests}

The authors declare that they have no competing interests.

\section{Author details}

'Laboratório de Diptera, Instituto Oswaldo Cruz (FIOCRUZ), Rio de Janeiro, Brasil. 2Programa de Pós-Graduação em Biologia Animal, Instituto de Biologia, Universidade Federal Rural do Rio de Janeiro, Seropédica, Rio de Janeiro, Brazil. ${ }^{3}$ Laboratorio Interdisciplinar de Vigilância Entomológica em Diptera e Hemiptera, Instituto Oswaldo Cruz (FIOCRUZ), Rio de Janeiro, Brasil. ${ }^{4}$ Universidade Nova Iguaçu, Nova Iguaçu, Rio de Janeiro, Brazil. ${ }^{5}$ Fundação Centro Universitário Estadual da Zona Oeste (UEZO), Rio de Janeiro, Brazil. ${ }^{6}$ Centro Universitário de Volta Redonda (UniFOA), Volta Redonda, Rio de Janeiro, Brazil. 7 , Brazil, Rio de Janeiro. ${ }^{8}$ Laboratório de Educação Profissional em Vigilância em Saúde (LAVSA), Escola Politécnica de Saúde Joaquim Venâncio, Fundação Oswaldo Cruz (FIOCRUZ), Rio de Janeiro, Brazil. ${ }^{9}$ Instituto de Aplicação Fernando Rodrigues da Silveira (Cap-UERJ), Universidade do Estado do Rio de Janeiro (UERJ), Rio de Janeiro, Brazil.

Received: 5 October 2021 Accepted: 17 November 2021 Published online: 27 November 2021

\section{References}

1. World Health Organization. World Health Statistics 2018: Monitoring Health for the SDGs, Sustainable Development Goals. World Health Organization, Geneva; 2018. https://apps.who.int/iris/handle/10665/ 272596. Accessed 20 May 2021.
2. Harbach RE. Mosquito taxonomic inventory. Culicidae classification. Natural History Museum, London, UK; 2021. https://mosquito-taxonomicinventory.info/simpletaxonomy/term/6045. Accessed 2 Jul 2021.

3. Wilkerson RC, Linton Y-M, Fonseca DM, Schultz TR, Price DC, Strickman DA. Making mosquito taxonomy useful: a stable classification tribe Aedini that balances utility with current knowledge of evolutionary relationships. PLoS ONE. 2015;10:e0133602.

4. Alencar J, de Mello CF, Gil-Santana HR, Guimarães AÉ, de Almeida SA, Gleiser RM. Vertical oviposition activity of mosquitoes in the Atlantic Forest of Brazil with emphasis on the sylvan vector, Haemagogus leucocelaenus (Diptera: Culicidae). J Vector Ecol. 2016;41:18-26.

5. Mondet B, Vasconcelos PFC, da Rosa TAPA, da Rosa TES, Rodrigues SG, da Rosa TJFS, et al. Isolation of yellow fever virus from nulliparous Haemagogus (Haemagogus) janthinomys in eastern Amazonia. Vector Borne Zoonotic Dis. 2002;2:47-50.

6. Araújo FAA, Ramos DG, Santos AL, Passos PHO, Elkhoury ANSM, Costa ZGA, et al. Epizootias em primatas não humanos durante reemergência do vírus da febre amarela no Brasil, 2007 a 2009. Epidemiol Serv Saude. 2011;20:527-36.

7. Abreu FVS, Ribeiro IP, Ferreira-de-Brito A, Santos AACD, Miranda RM, Bonelly IS, et al. Haemagogus leucocelaenus and Haemagogus janthinomys are the primary vectors in the major yellow fever outbreak in Brazil, 2016-2018. Emerg Microbes Infect. 2019;8:218-31.

8. Lopes J, da Silva MAN, Oliveira VDRB, Borsato AM, Braga MCP. Ecologia de mosquitos (Diptera: Culicidae) em criadouros naturais e artificiais de área rural do norte do Estado do Paraná, Brasil. III. Viabilização de recipientes como criadouro. Semina Cienc Biol Saude. 1995:16:244-53.

9. Clements AN. The biology of mosquitoes development, nutrition and reproduction, vol. 1. London: Chapman and Hall; 1992.

10. Fader JE. The importance of interspecific interactions on the present range of the invasive mosquito Aedes albopictus (Diptera: Culicidae) and persistence of resident container species in the United States. J Med Entomol. 2016;53:992-1001.

11. Alencar J, Gleiser RM, Morone F, Mello CFD, Silva JS, Serra-Freire NM, et al. A comparative study of the effect of multiple immersions on Aedini (Diptera: (ulicidae) mosquito eggs with emphasis on sylvan vectors of yellow fever virus. Mem Inst Oswaldo Cruz. 2014;109:114-7.

12. Serpa LLN, Kakitani I, Voltolini JC. Competição entre larvas de Aedes aegypti e Aedes albopictus em laboratório. Rev Soc Bras Med Trop. 2008:41:479-84.

13. Marcondes $C B$, Alencar J. Revisión de los mosquitos del género Haemagogus Williston (Diptera: Culicidae) de Brasil. Rev Biomed. 2010;21:221-38.

14. Juliano SA. Species interactions among larval mosquitoes: context dependence across habitat gradients. Ann Rev Entomol. 2009;54:37-56.

15. Plano de Manejo Rebio Tinguá. Plano de Manejo Rebio Tinguá; 2006. https://rebiotingua.eco.br/planodemanejo.php/. Accessed 3 Mar 2020.

16. Lane J. Neotropical culicidae, vol. 1. São Paulo: Editora Universidade de São Paulo; 1953.

17. Lane J. Neotropical culicidae, vol. 2. São Paulo: Editora Universidade de São Paulo; 1953.

18. Arnell JH. Mosquito studies (Diptera, Culicidae) XXXII. A revision of the genus Haemagogus. Contrib Am Entomol Inst. 1973;10:1-174.

19. Forattini OP. Culicidologia médica, vol. 2. São Paulo: Editora Universidade de São Paulo; 2002.

20. Shannon CE. A mathematical theory of communication. Bell Syst Tech J. 1948;3:379-656.

21. Elliott JM. Statistical analysis of samples of benthic invertebrates, 2nd edn Freshwater Biological Association: England; 1977.

22. Ludwig JA, Reynolds JF. Statistical ecology. A primer on methods and Lane, computing. Wiley: New York; 1988.

23. Shapiro SS, Wilk MB. An analysis of variance test for normality (complete samples). Biometrika. 1965;52:591-611.

24. Zar JH. Biostatiscal analysis. New Jersey: Prentice-Hall; 2009.

25. Siegel S. Estatística não-paramétrica: para a ciência do comportamento. São Paulo: McGrawhill do Brasil; 1975.

26. Ayres M, Ayres Jr M, Ayres DL, Santos AA. BioEstat: aplicações estatísticas nas áreas das ciências biológicas e biomédicas. Sociedade Civil Mamirauá: MCT-CNPq, Belém, 2007. 
27. BioEstat, 5.0. BioEstat. Dowland de Arquivos. 2009 https://www.mamir aua.org.br/download/index.php?dirpath=./BioEstat\%205\%20Portugues\& order=0. Accessed 5 Mar 2019.

28. Hammer O, Harper DAT, Ryan PD. Past: paleontological statistic software package for education and data analysis. Paleontol Eletron. 2001;4:1-9.

29. Gotelli NJ, Entsminger GL. EcoSim: null models software for ecology, vol. 7. Acquired Intelligence Inc and Kesey-Bear (software on the Internet): 2009. Published by the authors. garyentsminger. com/ecosim. Accessed 2 May 2021.

30. Stone L, Roberts A. The checkerboard score and species distributions. Oecologia. 1990;85(1):74-9.

31. Barbosa AA, Navarro-Silva MA. Preferência por local de oviposição de Aedes albopictus (Skuse) (Diptera, Culicidae), em relação à presença de imaturos da própria espécie, sob condições de laboratório. Rev Bras Zool. 2002;19:1147-52.

32. Silva SOF, De Mello CF, Figueiró R, Docile T, Serdeiro M, Fumian FF, et al. Oviposition behavior of wild yellow fever vector mosquitoes (Diptera: Culicidae) in an Atlantic Forest fragment, Rio de Janeiro state, Brazil. Sci Rep. 2021;11:6081.

33. Bentley MD, Day JF. Chemical ecology and behavioral aspects of mosquito oviposition. Ann Rev Entomol. 1989;34:401-21.

34. Zequi JAC, Lopes J, Medri IM. Imaturos de Culicidae (Diptera) encontrados em recipientes instalados em mata residual no munícipio de Londrina, Paraná, Brasil. Rev Bras Zool. 2005;22:656-61.

35. Honório NA, Lourenço-de-Oliveira R. Frequency of Aedes aegypti and Aedes albopictus larvae and pupae in traps, Brazil. Rev Saude Publica. 2001;35:385-91.

36. Beier JC, Patricoski C, Travis M, Kranzfelder J. Influence of water chemica and environmental parameters on larval mosquito dynamics in tires. Environ Entomol. 1983;12:434-8.

37. Marques CCA, Marques GRAM, Brito M, Neto LGS, Ishibashi VC, Gomes FA. Estudo comparativo de eficácia de larvitrampas e ovitrampas para vigilância de vetores de dengue e febre amarela. Rev Saude Publica. 1993;27:237-41

38. Alencar J, Gil-Santana HR, Lopes CM, Santos JS, Guimarães AÉ. Utilização de armadilha "ovitrampa" para monitoramento de Haemagogus janthinomys (Diptera, Culicidae) em área de Mata Atlântica. Entomol Vectores. 2004;11:369-74.
39. Chadee DD, Corbet PS, Greenwood JJD. Egg-laying yellow fever mosquitoes avoid sites containing eggs laid by themselves or by conspecifics. Entomol Exp Appl. 1990;57:295-8.

40. Docile TN, Figueiró R, Honório NA, Baptista DF, Pereira G, Dos Santos JAA, et al. Frequency of Aedes sp. linnaeus (Diptera: Culicidae) and associated entomofauna in bromeliads from a forest patch within a densely urbanized area. Neotrop Entomol. 2017:46:613-21.

41. Schoener TW. Resource partitioning in ecological communities. Science. 1974;185:27-39.

42. Gotelli NJ, Graves GR. Null models in ecology. Washington DC: Smithsonian Institution Press; 1996.

43. Price PW. Insect Ecology. 2nd ed. New York: Wiley; 1984

44. Hwang YS, Kramer WL, Mulla MS. Oviposition attractants and repellents of mosquitoes. J Chem Ecol. 1980;6:71-80.

45. Barker-Hudson P, Jones R, Kay BH. Categorization of domestic breeding habitats of Aedes aegypti (Diptera: Culicidae) in Northern Queesnland. Australia J Med Entomol. 1988;25:178-82.

46. Begon M, Townsend CR, Harper JL. Ecologia- de Indivíduos a Ecossistemas. 4th ed. Porto Alegre: Artmed; 2007.

47. Couto-Lima D, Andreazzi CS, Leite PJ, Bersot MIL, Alencar J, Lourençode-Oliveira R. Seasonal population dynamics of the primary yellow fever vector Haemagogus leucocelaenus (Dyar \& Shannon) (Diptera: Culicidae) is mainly influenced by temperature in the Atlantic Forest, southeast Brazil. Mem Inst Oswaldo Cruz. 2020;115:e200218.

48. Tátila-Ferreira A, Maia DA, Abreu FVS, Rodrigues WC, Alencar J. Oviposition behavior of Haemagogus leucocelaenus (Diptera: culicidae), a vector of the wild yellow fever in Brazil. Rev Inst Med Trop São Paulo. 2017;7(59):e60

49. Camargo-Neves VLF, Poletto DW, Rodas LAC, Pachioli ML, Cardoso RP, Scandar SAS. Entomological investigation of a sylvatic yellow fever area in São Paulo State, Brazil. Cad Saude Publica. 2005;21:1278-86.

\section{Publisher's Note}

Springer Nature remains neutral with regard to jurisdictional claims in published maps and institutional affiliations.
Ready to submit your research? Choose BMC and benefit from:

- fast, convenient online submission

- thorough peer review by experienced researchers in your field

- rapid publication on acceptance

- support for research data, including large and complex data types

- gold Open Access which fosters wider collaboration and increased citations

- maximum visibility for your research: over 100M website views per year

At BMC, research is always in progress.

Learn more biomedcentral.com/submissions 